\title{
Research on the Path of College-enterprise Cooperation of Private Colleges in Shaanxi Province Based on the International Experience
}

\author{
Jiaojiao Mo \\ Xi'an Peihua University, Xi'an, 710125, China
}

\begin{abstract}
Keywords: College-enterprise cooperation, Private Colleges in Shaanxi province, International experience
\end{abstract}

\begin{abstract}
The practice of the private colleges in developed countries proves that colleges-enterprise cooperation is an effective way to train skilled talents. The cooperation experiences of colleges and enterprises in foreign countries can effectively solve the existing problems in the college-enterprise cooperation in Shaanxi province. Shaanxi private colleges should strengthen legislative protection, establish special organization and develop various models of college-enterprise to realize the new win-win situation of colleges and enterprises.
\end{abstract}

\section{Current Situation of College-enterprise Cooperation of Private Colleges in Shaanxi Province}

At present, there are a total of 30 private colleges in Shaanxi. In the course of the development of Shaanxi private colleges, a group of educators who are enthusiastic about the cause of private colleges have emerged. They are enthusiastic about the cause of education, with a strategic vision and perseverance of the spirit of struggle for the development of private colleges in Shaanxi to make outstanding contributions. Colleges and enterprises belong to two different interest groups, the two sides can cooperate for a long time, the need for national laws and regulations and policy constraints. Although China has developed a number of policies to support the development of school enterprise cooperation, but there is still a lack of the necessary legal and institutional protection, resulting in the development of private enterprises in Shaanxi province there are many difficulties in school enterprise cooperation. At present, many private colleges in Shaanxi Province in the process of cooperation between colleges and enterprises, the lack of overall planning, although some enterprises with the signing of the agreement, but the students in the practice of enterprise content and the professional knowledge of the phenomenon of disjointed. Many enterprises in society are still affected by the traditional concept of the existence of cognitive bias of private college students, leading to the practice of private colleges do not have the enthusiasm of enterprises in the link. Even if some enterprises can receive private college student internships, in the specific implementation, but also the enterprise according to the production needs to arrange. They cannot be arranged according to the student curriculum, professional settings. Obviously, the operation and development of the school enterprise cooperation in Shaanxi private colleges have more difficulties and pressures compared with public colleges. On the other hand, for the practical interests of enterprises to provide only internship positions, failed to fully consider the students professional, resulting in professional positions and students do not match. The school enterprise cooperation has appeared for the cooperation and the cooperation, the student for the practice and the practice situation, has not been able to exercise the student practical ability, raises the high quality practical talented person's goal.

\section{Common Models of College-enterprise Cooperation in Foreign Countries}

The cooperative education mode in America generalized occupation abilities and interests as training objectives, combined with labor, and the teaching principle of sandwich. Training objectives according to job requirements determined by the Specialized Committee, and the training goal based training teaching module the ability, the teacher according to the teaching rules according to the corresponding knowledge module of teaching, at the same time, the school according to the students' professional and interested in finding the appropriate enterprise, according to the needs of enterprises 
and may provide the corresponding production practice training places and rewards signed a contract, clearly the rights and obligations. Based on the theory teaching, the teaching activities will be carried out alternately in the school and the enterprise. The provisions of the German occupation technology education law, more than half of young people to accept the occupation technology education, then these young people will enter the factory to become the apprentice, and enter the higher occupation school learning theory, the theory and practice of full integration, improve the actual work ability of youth. Sandwich model in British is a kind of training mode of "theory-practice-theory". Its main characteristic is that in the process of students' learning, it is necessary to arrange the term of work, and the students take part in the post work as a "professional" in the term of the work. This mode of education can help students better understand the theory of knowledge, grasp the more important management skills and knowledge production in the production process, familiar with the status of their activities in the whole production process and the production procedure and relationship continuity.

\section{International Experience of College-enterprise Cooperation}

Legislative Safeguard of College-enterprise Cooperation. Colleges and enterprises belong to two different interest groups, the two sides can cooperate for a long time, the need for national laws and regulations and policy constraints. Throughout the development of the cooperation between enterprises in the developed countries, the legislation is the basic guarantee. In 1996, the European Commission published a white paper, strengthening college-enterprise cooperation. The development of various forms of apprenticeship training strengthened students' employment ability, establish the network center of apprenticeship training in member states. The government of Norway to take effective measures to encourage enterprises to participate in the occupation education, industry, using legal form to determine the occupation education development and standardize enterprise industry responsibility, the occupation education center. In order to encourage the development of enterprise based training, the Norway government has increased the efforts of government funding, the training institutions accept the apprentice by county authorities give some subsidies. In Norway, the Department of education is not only the occupation education has unique territory, the business sector, the economic sector, the employer organizations are increasingly involved in the occupation education, and school contact local institutions have become increasingly frequent, the development of occupation education in colleges has become a local human resource center. It is the duty of the apprenticeship and the industrial training board to advise the provincial minister of education on the training and qualification of the profession and the type of work.

Special Agency of College-enterprise Cooperation. The British government set up the "industrial cooperation committee" to control and supervise the enterprises and colleges, and to give some financial compensation to the enterprises that cooperate with the school. Do not rely on university personnel training business increased certain taxes, and the public because of low levels of education cannot meet the business needs of the list of colleges, to reduce or stop the financial support, in order to promote mutual cooperation between colleges and enterprises. On the one hand, according to the proportion of financial support given to the school to share the results of education; on the other hand, colleges need to train personnel through the enterprise, to receive financial assistance from the enterprise. At present, many colleges in the process of cooperation between colleges and enterprises, the lack of overall planning, although some enterprises with the signing of the agreement, but the students in the practice of enterprise content and the professional knowledge of the phenomenon of disjointed. It is very difficult for colleges to achieve the goal of cultivating high-quality applied talents from the cooperation between colleges and enterprises, and it is very difficult for enterprises as economic entities to obtain practical benefits from the cooperation between colleges and enterprises.

Various Models of College-enterprise Cooperation. Since the 50s of last century, the research on the school enterprise cooperation has been very common, which has formed an effective and diversified school enterprise cooperation mode which is suitable for our country. The typical mode of 
cooperation between college and enterprise is Germany's "dual system", "cooperative education" in the United States, "TAFE education" in Australia, "Sandwich" in Britain and so on. Dual system is a kind of school running system supported by national legislation. France's school enterprise cooperation education is more unique, vocational colleges in each classroom is a teaching plant, experimental teaching conditions are very complete, combined with outside school practice, graduates can go out to use.

\section{Development Suggestions of College-enterprise Cooperation of Private Colleges in Shaanxi Province Based on the International Experience}

Strengthen Legislative Protection. The cooperation between colleges in Shaanxi province is lack of relevant policies and measures at the national level. We have to firm students practice education subsidies, to give businesses tax incentives, allow enterprises to improve the enthusiasm of cooperation, let the school enterprise cooperation mechanism increased the interest level from the emotional level prior to the institutional level, promote the integration of school and enterprise cooperation depth. The government should play a leading role in the cooperation, further improve the relevant laws and regulations of the school enterprise cooperation, school enterprise cooperation, clear responsibility, right and benefit, the cooperation according to law. The government is the macro-control of vocational education, but also the formulation of policy makers and funding providers. Perfecting the laws and regulations of vocational education is the prerequisite for the healthy development of school enterprise cooperation. Develop the cooperation laws and regulations, clear the rights and obligations of colleges and enterprises in the cooperation, to ensure that enterprises in cooperation in the interests of the school, the school enterprise cooperation to promote enterprises to achieve win-win situation, mobilize the enthusiasm of enterprises participating in the cooperation, and to establish a long-term effective mechanism. Through legislation, strengthening labor access system, the first training after employment, without training employment shall not become a system, guide people attach importance to occupation education and training, improve the social status of occupation education, greatly improve the degree of dependence of business cooperation. At the same time, private colleges in Shaanxi province should strictly supervise and inspect the occupation qualification system, intensify the implementation of occupation qualification system supervision, in violation of the provisions, random recruiting without occupation education or training personnel of the employer to give punishment, and ordered its deadline for training of relevant personnel.

Establish Special Organization. From the experience of foreign cooperation, the cooperation needs the coordination or management mechanism, its main functions are: to promote the social consensus on cooperation; serves as a bridge between school and enterprise; to assist in the establishment of school enterprise cooperation network, and the organization, management and coordination of the project; and reform of teaching and guidance consultation of professional talent training. In terms of the composition of institutional personnel, the coordination and management of Shaanxi private colleges have begun to take shape, but its function has not been brought into play. The combination of work and study is an important guarantee for the implementation of the work study combination. The college has set up a working committee of the school enterprise cooperation, by the president as chairman. The Admissions Office of the office, the Department Leadership Committee, working committee is responsible for coordinating the cooperation work of school enterprise cooperation and work study combination. The cooperation projects are the establishment of a working group, the team arranged a specific person in charge and liaison, hired executives as a member of the specific person in charge of the base or workshop as the person in charge of the project enterprise.

Develop Various Methods. Private colleges in Shaanxi province should learn from the running mode of occupation education occupation education abroad. In order to improve the ability of personnel training in school enterprise cooperation, it is necessary to study the experience of cultivating talents in foreign university and enterprise cooperation, to study the teaching mode in 
Shaanxi Province to explore new and more scientific teaching methods. Absorb experience and promote development. School enterprise cooperation is a long-term, sustainable development of personnel training mode, Germany's "dual system" personnel training mode to uphold the principle of development. Our province enterprise cooperation mode is not mature and perfect, need on the existing basis, formulate relevant laws and regulations, from the successful experience in teaching innovation and development, promote the talent training mode of school enterprise cooperation work and rapid development. In order to further promote the training mode of school enterprise cooperation and integration of engineering talent, private universities should continue to increase the practice base construction, and the university is looking for professional counterparts to establish cooperative relations with the enterprise, further, make it really become a practice base for student theoretical knowledge, and become a cradle of companies looking for talent reserve.

\section{Conclusion}

The college-enterprise cooperation of Shaanxi private colleges is a systematic project. First of all, the government should pay attention to establish the formulation and implementation of laws and regulations. Secondly, private colleges in Shaanxi should set up special agencies to coordinate the problems arising from the college-enterprise cooperation. Finally, colleges and enterprises should break the old habit of thinking to develop a variety of models of the cooperation in order to train more talented students.

\section{Acknowledgement}

This research is the result of the "Subject of the 13th Five-year Plan of Education Science in Shaanxi Province in 2016" (Grant No. SGH16H251). The name of the project is "Research on Deep Cooperation Mechanism of Private Colleges of Application Technology in Shaanxi and Enterprises from the Win-win Perspective”.

\section{References}

[1] Lian Lifang, Strengthening College- Enterprise Convergence, Achieving "Zero Distance" between Graduation and Employment-Practice and Experience of College-Enterprise Cooperation of Meizhou Bay Technology College [J]. Journal of Mudanjiang College of Education, 2011(2): 84-86.

[2] Liu Zhonghua, On the Improvement of China's Higher Vocational Education Mode Based on International Experience of College-Enterprise Cooperation [J]. Journal of Xiangfan Vocational and Technical College, 2012, 11(6):12-+14+18.

[3] Tang Guangwei, Zhang Yaping, Reflection on the Advanced Experience of Vocational Education Accelerating the College-enterprise Cooperation in Developed Countries [J]. Journal of Wuhan Polytechnic, 2010(4): 90-93.

[4] Li Haizong, Yang Yueming, Experience of Running a Corporate University and Its Enlightenment for College-Enterprise Cooperation [J]. Adult Education, 2011(12):106-107. 